\title{
A comparative study of two live measles vaccines in Iran
}

\author{
BY H. MIRCHAMSY, A. SHAFYI, Y. BASSALI, \\ S. BAHRAMI AND F. NAZARI \\ Razi Serum Institute, P.O. Box 656, Tehran, Iran
}

(Received 25 August 1969)

\section{SUMMARY}

The results of immunization of 523 children from 9 months to over 5 years of age with two attenuated measles vaccines, 'Denken' and 'Biken', are described. The clinical reactions following vaccination with both vaccines were mild, but Denken vaccine produced more rashes than the Biken vaccine. The serological conversion was satisfactory for both vaccines but a higher titre of neutralizing and haemagglutination-inhibiting antibodies was found in children immunized with Denken vaccine. The incidence of severe reactions or complications was negligible in this trial. The immunity to diphtheria or tetanus was not altered by vaccination with live measles vaccine.

\section{INTRODUCTION}

Since the introduction of the first live attenuated measles vaccine, Edmonston B. Strain (Enders, Katz, Milovanovic \& Holloway, 1960) several variants of this vaccine, based on difference in number of passages of the same strain of virus in susceptible host cells, have been developed (Schwarz, Moraten, Beckenham, further attenuated Beckenham 31 and Milovanovic's strains). In Russia (Fadeeva, Dadashyan, Lebedev \& Zhdanov, 1960; Smorodintsev et al. 1960) vaccines were prepared by adapting two different strains of measles virus isolated by Russian workers to human and chick-embryo cell cultures. In Japan also 'Denken' vaccine was developed by Matumoto et al. $(1961 ; 1962)$ by attenuation of the Sugiyama strain, originally isolated in monkey kidney cell culture. It later underwent six passages in the same cell, six in human conjunctival-cell culture and 45 passages in primary bovine kidney cell. Another Japanese vaccine 'Biken' was first introduced by Okuno et al. (1960) from supernatant of chick-embryo amnioticmembrane emulsion. This strain was derived by 61 passages of the Toyoshima strain in chick-embryo amniotic membrane.

Since the Schwarz and Beckenham vaccines have been widely used in rural areas of Iran with a high percentage of protection (Nafyci et al. 1967) it was desirable to study the effectiveness of and the reactions produced by the other existing vaccines. This paper presents the results of clinical and serological follow-up of children immunized with Denken and Biken vaccines. 


\section{MATERIALS AND METHODS}

Study population

The five villages called Hessarak, Mehrdasht, Soufiabad, Heydarabad and Kamalabad located on a dry plateau area at an altitude of about 3000 feet, 40 miles west of Tehran, and around the Razi Institute were chosen for this study. The study population was made up of 523 healthy children, aged 9 months to 7 years, evenly distributed between the two sexes and without a known history of measles infection.

The vaccine trial was conducted at the end of January, when there was some snow most days. The children and their mothers were brought by cars to the dispensary of the Razi Institute, where vaccination was practised, and the children of each village were divided into three groups. One group received Denken vaccine, another group Biken vaccine and the last was injected with physiological saline.

\section{Surveillance}

The vaccinated children were observed by three physicians and 20 Public Health technicians who did not know which vaccine had been administered. Medical personnel were well trained to perform the follow-up examination. All information was recorded on a card containing spaces for identifying information, code numbers of vaccines, date of vaccination, daily temperature and significant reactions. The initial survey revealed the occurrence of a respiratory disease in the area. There was, however, no evidence of measles, diphtheria or any other infectious diseases. Rectal temperatures were measured at 9 a.m. and 4 p.m. each day from the 5 th to the 19 th day after immunization. All children with severe reactions were examined by physicians.

\section{Vaccines}

The following two live measles vaccines were used: (1) Denken lyophilized vaccine lot No. $2 \mathrm{~A}$, generously granted by Dr Hashizuma, Chief of the Measles Unit, Chiba Serum Institute, Ichikawa Chiba, Japan. (2) Biken lyophilized vaccine lot No. 6803 kindly supplied by Professor Okuno, Director, Research Institute for Microbial Diseases, Osaka University, Suita City, Osaka, Japan.

Physiological saline was used as placebo for inoculation of the children in the control group. Both vaccines were shipped by air-freight in dry ice and were then kept at $-20^{\circ} \mathrm{C}$. until used. Children were immunized subcutaneously with 500 TCID 50 of vaccine in a volume of $0.25 \mathrm{ml}$.

\section{Serological techniques}

Paired bloods of 449 children ( $85 \%$ of the total children under study) were collected immediately before inoculation of vaccine and 30 days later. The blood was collected from finger pricks using paper disks as described previously (Mirchamsy, Nazari, Stellman \& Esterabady, 1968). All specimens were kept in envelopes in a dry and cool place before use. Each pair of sera was tested by neutralization and haemagglutination-inhibition tests. 


\section{Neutralization test}

Each disk of filter paper was soaked overnight at $4^{\circ} \mathrm{C}$. in $0.8 \mathrm{ml}$. of sterile distilled water and serum was removed by centrifugation. This dilution was accepted as $1 / 4$ serum dilution. Before each test this serum dilution was heated at $56^{\circ} \mathrm{C}$. for $30 \mathrm{~min}$. Neutralization was performed in Vero cell cultures as follows. Replicate monolayers containing $5 \times 10^{5}$ Vero cells grown in tubes, as described previously (Mirchamsy \& Rapp 1969), were infected with $0.2 \mathrm{ml}$. of a mixture of equal amounts of 50 TCID 50 of Edmonston strain of measles virus and serum dilution incubated for $1 \mathrm{hr}$. at $37^{\circ} \mathrm{C}$. Serum dilutions of $1 / 16$ to $1 / 1024$ were used. After an adsorption period of $1 \mathrm{hr}$. at $37^{\circ} \mathrm{C} .1 \cdot 3 \mathrm{ml}$. of maintenance medium was added to each tube. Observation of cytopathic changes was made for 7 days. The neutralization titre (NT) was expressed as negative log, to base 2 , of the serum dilution.

\section{Haemagglutination-inhibition (HAI) test}

Haemagglutinin (HA) was partly purchased from commercial laboratories and partly prepared according to Rosen's Technique (Rosen, 1961) but using Vero cells instead of KB cells. Three lots of virus prepared by this technique had haemagglutinin titres of $1 / 64,1 / 32$ and $1 / 64$.

For the haemagglutination test we used a $0.5 \%(\mathrm{v} / \mathrm{v})$ suspension of vervet monkey erythrocytes in phosphate-buffered saline (PBS). The HA titre was determined by incubating at $37^{\circ} \mathrm{C}$. a mixture of $0.2 \mathrm{ml}$. of each of twofold serial dilutions of HA and $0.2 \mathrm{ml}$. of $0.5 \%$ red cell suspension. The test was performed in special Plexiglass plates (Flow laboratories) made for HA titration and was read after $2 \mathrm{hr}$. The highest dilution showing complete agglutination of cells was considered to contain one HA unit.

Equal volumes of $0.2 \mathrm{ml}$. of the $1 / 4$ dilution of serum to be tested and a $25 \%(\mathrm{w} / \mathrm{v})$ suspension of acid-washed kaolin in PBS ( $\mathrm{pH} 7 \cdot 2)$ were mixed, shaken for $20 \mathrm{~min}$. at room temperature, and centrifuged at $2000 \mathrm{rev} . / \mathrm{min}$. for $15 \mathrm{~min}$. The clear supernatant was used as treated serum. For the HAI test, $0 \cdot 1 \mathrm{ml}$. of twofold serial dilutions of the treated serum was mixed with $0.1 \mathrm{ml}$. of haemagglutinin containing four HA units. The tubes were incubated at $37^{\circ} \mathrm{C}$. for $1 \mathrm{hr}$., $0.2 \mathrm{ml}$. of the monkey erythrocyte suspension was added, and the tubes were incubated at $37^{\circ} \mathrm{C}$. for $2 \mathrm{hr}$. and at $4^{\circ} \mathrm{C}$. overnight. The HAI titre was expressed as the negative $\log _{2}$ of the highest serum dilution showing complete HA inhibition. In each test, HA titration, standard serum titration and red cell controls were included. This test was performed with dilutions of each serum from 1/8 to 1/1024.

\section{Standard serum}

The pooled sera of five adults with high neutralization and HAI titres was distributed in ampoules of $0.5 \mathrm{ml}$. and was kept at $-20^{\circ} \mathrm{C}$. In each test a sample of this serum was used as standard serum. 


\section{Diphtheria and tetanus antitoxin titration}

In order to follow possible variations in immunity to diphtheria and tetanus due to measles immunization, 56 pairs of sera of children under measles study, having a know history of immunization against diphtheria and tetanus, were selected for antitoxin titration according to the procedure described earlier (Mirchamsy et al. 1968).

\section{RESULTS}

\section{Study population}

The assessment of the study group according to vaccines used is as follows: of 523 children initially immunized, 272 received Denken vaccine, 161 were immunized with Biken vaccine and 90 received physiological saline as placebo. Of 272

Table 1. Age and sex distribution of inoculated children

\begin{tabular}{|c|c|c|c|c|c|c|c|}
\hline \multirow{3}{*}{$\begin{array}{c}\text { Type } \\
\text { of } \\
\text { vaccine }\end{array}$} & \multirow[b]{3}{*}{ Inoculated } & \multirow{2}{*}{\multicolumn{2}{|c|}{ Sex }} & \multicolumn{4}{|c|}{ Age } \\
\hline & & & & & & & \\
\hline & & Female & Male & months & years & years & years \\
\hline Denken & 272 & 124 & 148 & 71 & 65 & 68 & 68 \\
\hline Biken & 161 & 78 & 83 & 41 & 43 & 41 & 36 \\
\hline Placebo & 90 & 37 & 53 & 27 & 24 & 18 & 20 \\
\hline
\end{tabular}

Table 2. Number of children developing pyrexia

\begin{tabular}{|c|c|c|c|c|c|c|c|}
\hline \multirow{3}{*}{$\begin{array}{l}\text { Type of } \\
\text { vaccine }\end{array}$} & \multirow{3}{*}{$\begin{array}{l}\text { No. of } \\
\text { children } \\
\text { clinically } \\
\text { assessed }\end{array}$} & \multicolumn{6}{|c|}{ Pyrexia } \\
\hline & & \multicolumn{2}{|c|}{$37 \cdot 4-38^{\circ} \mathrm{C}$} & \multicolumn{2}{|c|}{$38-39^{\circ} \mathrm{C}$. } & \multicolumn{2}{|c|}{$>39^{\circ} \mathrm{C}$} \\
\hline & & No. & $\%$ & No. & $\%$ & No. & $\%$ \\
\hline Denken & 249 & 177 & 71 & 34 & 14 & 9 & $3 \cdot 6$ \\
\hline Biken & 138 & 64 & 46 & 24 & 17 & 8 & $5 \cdot 8$ \\
\hline Placebo & 72 & 44 & 61 & 4 & $5 \cdot 6$ & 4 & $5 \cdot 6$ \\
\hline
\end{tabular}

Table 3. Distribution of children by incubation periods of pyrexia

$\begin{array}{lccc}\text { Type of } & \begin{array}{c}\text { Onset } \\ \text { mean days }\end{array} & \begin{array}{c}\text { Mean duration } \\ \text { of pyrexia } \\ \text { (days) }\end{array} & \begin{array}{c}\text { Mean duration } \\ \text { of maximum } \\ \text { temperature } \\ \text { (days) }\end{array} \\ \text { Denken } & \mathbf{9 \cdot 1 1} & 3 \cdot 83 & 2 \cdot 7 \\ \text { Biken } & 9.4 & 2 \cdot 66 & 2 \cdot 4 \\ \text { Placebo } & - & 1 \cdot 17 & 1\end{array}$

children immunized with Denken vaccine, 249 were clinically observed, paired blood samples were obtained from 256 children, 13 of them had measles antibodies before immunization and were excluded from the analysis. Of 161 subjects vaccinated with Biken vaccine, 138 were clinically examined, 159 paired blood samples were collected before and 30 days after immunization, 15 children had 
natural measles antibodies and were not included in this study. Of 90 placebo group, 72 were in the clinical follow-up, 76 paired samples of blood were collected but because five children of this group had natural measles antibodies, 71 pairs of blood samples were included in our study. The age and sex distributions of children are shown in Table 1.

\section{Clinical response}

The clinical findings are summarized in Tables 2-6. The onset of fever was 9·11 and $9 \cdot 4$ days on the average after immunization with Denken and Biken vaccines respectively (Table 3). The duration of fever was 3 to 4 days for both vaccines in

Table 4. Pyrexia variations according to age group

\begin{tabular}{|c|c|c|c|c|}
\hline \multirow[b]{2}{*}{$\begin{array}{l}\text { Type of } \\
\text { vaccine }\end{array}$} & \multicolumn{2}{|c|}{$9-12$ months } & \multicolumn{2}{|c|}{$>1-2$ years } \\
\hline & $\begin{array}{l}\text { Mean } \\
\text { duration } \\
\text { (days) }\end{array}$ & $\begin{array}{c}\text { Mean max. } \\
\text { fever } \\
\left({ }^{\circ} \mathrm{C} .\right)\end{array}$ & $\begin{array}{c}\text { Mean } \\
\text { duration } \\
\text { (days) }\end{array}$ & $\begin{array}{l}\text { Mean max. } \\
\text { fever } \\
\left({ }^{\circ} \mathrm{C} .\right)\end{array}$ \\
\hline Denken & 4 & $38 \cdot 1$ & 3 & $37 \cdot 4$ \\
\hline Biken & 3 & $38 \cdot 5$ & 4 & $38 \cdot 3$ \\
\hline \multirow[t]{2}{*}{ Placebo } & 1 & 38 & 3 & $37 \cdot 9$ \\
\hline & \multicolumn{2}{|c|}{$>2-5$ years } & \multicolumn{2}{|c|}{$>5$ years } \\
\hline Denken & 4 & $38 \cdot 3$ & 2 & 38 \\
\hline Biken & 3 & $38 \cdot 1$ & 1 & $37 \cdot 5$ \\
\hline Placebo & 2 & 38 & 1 & $37 \cdot 7$ \\
\hline
\end{tabular}

Table 5. Symptoms reported 7-18 days after immunization

\begin{tabular}{|c|c|c|c|c|c|c|c|}
\hline \multirow{2}{*}{$\begin{array}{l}\text { Type of } \\
\text { vaccine }\end{array}$} & \multirow{2}{*}{$\begin{array}{l}\text { No. of } \\
\text { children } \\
\text { clinically } \\
\text { assessed }\end{array}$} & \multicolumn{2}{|c|}{ Rash } & \multicolumn{2}{|c|}{ Koplik } & \multicolumn{2}{|c|}{ Coryza } \\
\hline & & No. & $\%$ & No. & $\%$ & No. & $\%$ \\
\hline Denken & 249 & 66 & 26.5 & 5 & 2 & 40 & 16 \\
\hline Biken & 138 & 12 & 8.7 & 3 & $2 \cdot 1$ & 17 & $12 \cdot 3$ \\
\hline Placebo & 72 & 1 & $1 \cdot 4$ & - & - & 6 & $8 \cdot 3$ \\
\hline
\end{tabular}

Table 6. Reactions and complications of live Denken and Biken measles vaccines in children under 2 years of age

\begin{tabular}{|c|c|c|c|c|c|c|c|}
\hline \multirow{2}{*}{$\begin{array}{l}\text { Type of } \\
\text { vaccine }\end{array}$} & \multirow{2}{*}{$\begin{array}{l}\text { No. of } \\
\text { children }\end{array}$} & \multicolumn{2}{|c|}{ Rash } & \multicolumn{2}{|c|}{ Koplik } & \multicolumn{2}{|c|}{ Coryza } \\
\hline & & No. & $\%$ & No. & $\%$ & No. & $\%$ \\
\hline Denken & 120 & 29 & $24 \cdot 1$ & 2 & 1.7 & 27 & $22 \cdot 5$ \\
\hline Biken & 42 & 9 & $21 \cdot 4$ & 2 & $4 \cdot 7$ & 12 & $28 \cdot 6$ \\
\hline Placebo & 42 & 1 & $2 \cdot 4$ & - & - & 5 & 11.9 \\
\hline
\end{tabular}

children under 5 years, 2 days for Denken and only 1 day for Biken in children over 5 years (Table 4). The pyrexia was mild in immunized children; as a matter of fact the majority of febrile reactions were mild, not exceeding $37 \cdot 4-38^{\circ} \mathrm{C}$. during the period of observation (Table 2). There was, on the other hand, the same range of temperature for the same percentage of controls. The pyrexia of the control 
苛

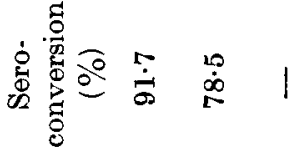

离

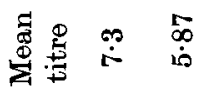

离

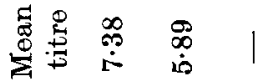

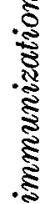

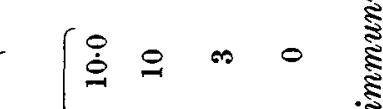

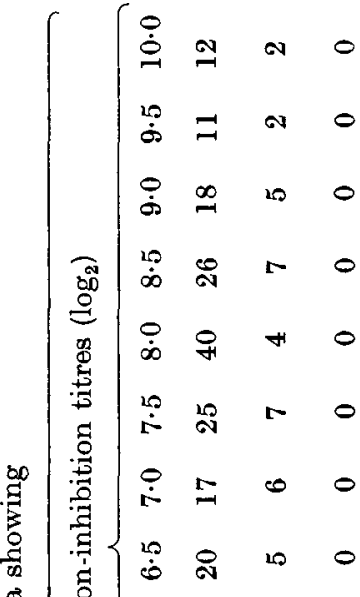

买

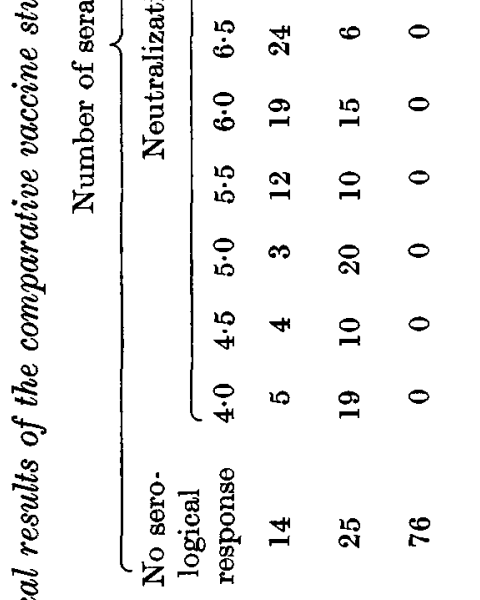

उ.

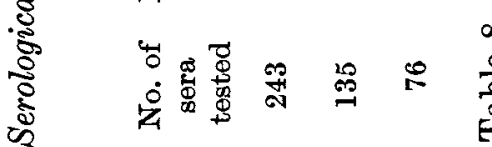

离

宽

हैँ

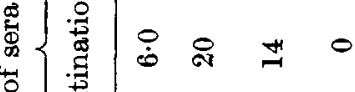

苟 劳

.

要

मी 10200

มี

is 1800

$\dot{\varphi} \rightarrow \infty 0$

तू

$\infty$ 
group, as well as coryza, cough and diarrhoea, was due to respiratory infection that was endemic in the area at the time of the study. The temperature of $38-39^{\circ} \mathrm{C}$. was observed in 14, 17 and $5.6 \%$ of subjects immunized with Denken vaccine, Biken vaccine and in the placebo group respectively. Despite the fever, malaise or lack of appetite was not observed. An exanthem was recorded in 66 out of 249 patients $(26.5 \%)$ immunized with Denken vaccine; this reaction was much lower following Biken vaccination, since only 12 of 138 children $(8.7 \%)$ showed the exanthem (Table 5). The duration of rash ranged between 1 and 3 days. It appeared first on the face as a mild maculopapular eruption. In no instance did the rash produce any disability. The Koplik spots were noticed among $2 \%$ of children immunized with either vaccine (Table 5). No evidence of central nervous involvement, bacterial infections, otitis or any other sequelae were observed in the vaccinated children.

\section{Serological findings}

In a preliminary study a comparison was carried out between neutralization, haemagglutination-inhibition and complement-fixation (CF) tests in some sera of children and adults. It was found that when Vero cells were used for the neutralization test as described above, a close correlation existed between neutralization titre and HAI titre if only 10-50 TCID 50 of Edmonston measles virus was used as test dose. In this case the test was performed in 5 days without need of changing medium. The tubes were read each day for cytopathic effect and the neutralization end point was determined when only $1 / 10$ virus test dose showed $50 \%$ cytopathic effect in virus titration. With regard to the CF test, lower titres were obtained when four units of $\mathrm{CF}$ antigen were used. The results of CF tests were not included in this study. Comparison was made between NT and HAI tests, and Tables 7 and 8 show the range of seroconversion following administration of Denken and Biken vaccines. The seroconversion was $94 \cdot 2 \%$ (NT) and $91.7 \%$ (HAI) following vaccination with Denken; $81.5 \%$ (NT) and $78.5 \%$ (HAI) after immunization with Biken. None of the children in the placebo group showed seroconversion. The existing titres against diphtheria and tetanus were not altered following immunization with live measles vaccine.

\section{DISCUSSION}

The high mortality due to natural measles complications, exceeding 10,000 cases a year in Iran (Nafyci et al. 1967) justified a regular mass campaign against the disease in remote rural areas of the country. Since 1965, attenuated and further attenuated measles vaccines have been successfully tested and widely used in various regions of Iran. In a comparative study Nafyci and his associates (1967) have noticed more severe reactions with attenuated measles vaccine than with further attenuated vaccine, and a high conversion rate for Edmonston B, Beckenham 31 and Schwarz vaccines in children of rural communities around Tehran. The present trial was designed to evaluate the two Japanese live measles vaccines 'Denken' and 'Biken', to compare their clinical and serological reactions with the other vaccines already studied and to examine the possibility of large-scale use of these vaccines. The study was carried out at a time when the incidence of a 
respiratory disease was high in the area but measles outbreaks had not been observed for 2 years. Both vaccines have been widely used in Japan. The incidence of elinical reactions in our study for Denken vaccine was lower than that observed in Japan (Matumoto et al. 1961; 1962). By inoculation of $0 \cdot 1$ to 10 TCID 50 of the Sugyama strain adapted to primary bovine renal cells, Matumoto and his associates (1962) have observed $70 \%$ incidence of pyrexia and $65 \%$ of rash among susceptible children of various age groups. These results are comparable with those noticed for the Edmonston B strain by Enders and for the Leningrad 4 strain used in Russia. The difference in incidence of fever and rash between our results and those of Matumoto and his associates can be attributed to the difference in passage numbers of the Sugyama strain in bovine renal cells. While these authors used the virus at its 28th passage in bovine kidney cells, the vaccine supplied by the Chiba Institute for this study has been prepared with the same strain at its 72nd passage in primary bovine renal cells. The average time of onset of rash recorded by Matumoto et al. was 13.4 and 18.5 days when 10 and 1 TCID 50 of virus were inoculated respectively. In our trial this average was reduced to $9 \cdot 11$ days, most probably because each dose of vaccine administered contained 500 TCID 50 of Sugyama virus. The persistence of rash, on average 3 days, is similar to the finding of the Japanese workers. The attenuated measles vaccine 'Biken', first developed by Okuno et al. (1960), was derived from the Toyoshima strain of measles virus. This virus was propagated in the amniotic membrane of the developing chick embryo. The Biken vaccine has been largely used in Japan and in Thailand (Ueda, Hosai, Minekawa \& Okuno, 1966) but to our knowledge in most field trials this vaccine has been used either by inhalation or after administration of a killed measles vaccine. In both cases the reactions were mild or inapparent. The seroconversion, on the other hand, was satisfactory especially when live Biken vaccine was used as a challenge vaccine, 3-4 weeks after inoculation of the killed vaccine. In our study the clinical reactions due to Biken vaccination were mild and similar to those observed for Denken vaccine. However, rash appeared in only $8.7 \%$ for Biken vaccine compared with $26.5 \%$ after Denken vaccine.

The serological responses are shown in Tables 7 and 8, from which it is evident that both vaccines had a strong immunogenic effect. There was a satisfactory correlation between NT and HAI antibodies; however, the neutralization test, which is more accurate, showed a somewhat higher percentage of seroconversion than the HAI test. This difference may be attributed to the presence of some nonspecific inhibitors which were not totally removed by kaolin. The close correlation between NT and HAI tests confirms the similar finding of Kunita, Kitavaki, Funahashi \& Toyoshima (1963).

It is also evident that a better serological response was obtained after immunization with Denken vaccine. We believe however that the stability of immunity will not be altered by the rather low antibody titres recorded for children immunized with Biken vaccine. Since the correlation between HAI activity and the immune response is controversial (Norrby, 1964; Parisius \& Macmorine, 1969) it was more accurate to evaluate the immune response by neutralization test. From the data presented we can assume that the effectiveness of Denken and Biken vaccines is 
similar to that of Schwarz and further attenuated Beckenham 31 vaccines previously studied in the same region around Tehran.

It is a matter of interest to compare data presented here (Table 6) with similar results observed by Nafyci and his associates (1967) with regard to the reactions and complications of attenuated and further attenuated measles vaccines in children under 2 years of age. Both trials have been made in the same plateau area of 3000 feet elevation. In our study $24 \cdot 1 \%$ and $21.4 \%$ rash, $1.7 \%$ and $4.7 \%$ Koplik spots were found after immunization with Denken and Biken vaccines respectively while $50 \%$ and $45 \%$ rash, $7 \%$ and $5 \%$ Koplik spots and $8 \%$ and $7 \%$ otitis were recorded by Nafyci et al. following vaccination with Edmonston B and Beckenham 31 vaccines respectively.

The immunization with live measles vaccine did not depress the immunity to diphtheria or tetanus.

We are grateful to Dr H. Morshed, Under Secretary of Ministry of Health, Iran, for his unfailing interest and encouragement. Acknowledgements are due to Dr M. Kaveh, Director, Razi Institute, for his support and encouragement. The main author wishes to thank Dr S. Hashizuma, Chief, Measles Virus Laboratory, Chiba Serum Institute, Chiba (Japan), Professor M. Matumoto, the Institute of Medical Science, the University of Tokyo, and Professor Y. Okuno, Director, Research Institute for Microbial Diseases, Osaka University, Suita City, Osaka (Japan), for all their helpful advice and for providing vaccines necessary for this study. We want also to thank Drs Moshir and Rahimian as well as all health technicians who participated in vaccination and clinical follow-up of this study.

\section{REFERENCES}

Enders, J. F., Katz, S. L., Milovanovic, M. V. \& Holloway, A. (1960). A study on an attenuated measles vaccine. I. Development and preparation of the vaccine; technics for assay of effects of vaccination. New England Journal of Medicine 263, 153.

Fadeeva, L. L., Dadashyan, M. A., Lebedev, D. D. \& Zhdanov, V. M. (1960). Attenuated measles virus strain in the U.S.S.R. American Journal of Diseases of Children 103, 379.

Kunita, N., Kitavaki, T., Funahashi, S. \& Toyoshima, K. (1963). Comparison of the haemagglutination inhibition test for measles with serological tests and its application to a field trial. Biken Journal 6, 45.

Matumoto, M., Mutai, M., Ogiwara, H. \& Nakamura, M. (1961). Prolifération du virus rougeoleux en culture de cellules rénales bovines. Comptes Rendus des Scéances de la Société de Biologie 155, 1192.

Matumoto, M., Mutai, M., Saburi, Y., Fujr, R., Minamitani, M. \& Nakamura, K. (1962). Live measles-virus vaccine : clinical trial of vaccine prepared from a variant of the Sugyama strain adapted to bovine kidney cells. Japanese Journal of Experimental Medicine $32,433$.

Mrrchamsy, H., Nazari, F., Stellman, C. \& Esterabady, H. (1968). The use of dried whole blood absorbed on filter-paper for the evaluation of diphtheria and tetanus antitoxins in mass surveys. Bulletin of the World Health Organization 38, 665.

Mirchamsx, H. \& Rapp, F. (1969). Role of interferon in replication of virulent and attenuated strains of measles virus. Journal of General Virology 4, 513.

Nafyci, K., Saidi, S., Nategh, R., Mostatab, A. \& Akbarshahy, R. (1967). Comparative study of live attenuated and further attenuated measles vaccines in rural areas of Iran. Archiv für die gesamte Virusforschung 22, 11.

Norrby, E. (1964). A sensitive measles HAI test. Proceedings of the International Symposium of Measles Vaccine Standardization. Measles and Rubella Serology, Lyon, France, page 186. 
Okuno, Y., Sugai, T., Toyoshima, K., Takahashr, M., Yamamura, T., Hata, S., Niki, T., NaKamuRA, K., UEDA, S. \& Kunta, N. (1960). Studies on the prophylaxis of measles with attenuated living virus. IV. Inoculation tests in children with chick embryo passage measles virus in 1960. Biken Journal 3, 293.

Parisius, W. \& Macmorine, H. G. (1969). Effects of tween 80 and Freon 113 on measles virus. Applied Microbiology 17, 379.

Rosen, L. (1961). Haemagglutination and haemagglutination-inhibition with measles virus. Virology 13, 139.

Smorodintsev, A. A., Baichuk, L. M., Shikina, E. S., Batanova, T. B., Bystryakova, L. V. \& Peradze, T. V. (1960). Clinical and immunological response to live tissue culture vaccine against measles. Acta Virologica (English edition), 4, 201.

Ueda, S., Hosal, H., Minekawa, Y. \& Okuno, Y. (1966). Studies on the combined use of killed and live measles vaccine. III. Conditions for the 'take' of live vaccine. Biken Journal 9, 97. 